\title{
Ictal water-seeking in nondominant temporal lobe seizures
}

回


Brain MRI (A), axial fluid-attenuated inversion recovery, and (B) coronal T2 showing mild right hippocampal atrophy, and (C) EEG showing a right temporal lobe seizure.

Supplemental data at Neurology.org
A 40-year-old woman with complex partial seizures and right hippocampal atrophy (figure, A and B) had persistent seizures after epilepsy surgery. One of her seizures is shown in the video on the Neurology ${ }^{\circledR}$ Web site at Neurology.org. She pushes the event button during the aura (rising epigastric sensation), rubs her mouth, reaches for water, and holds onto it through the seizure.

Peri-ictal water-seeking may localize to the nondominant temporal lobe based on the idea that temporal epileptiform discharges spread to hypothalamus causing thirst. ${ }^{1}$ Patients with nondominant temporal lobe epilepsy are more often able to react to external stimuli; they may react to the unpleasant feeling of thirst by water-seeking. ${ }^{2}$ Peri-ictal water-seeking is a stereotyped behavior associated with nondominant temporal lobe epilepsy but was not consistently seen in all seizures experienced by our patient.

Zubeda Sheikh, MD, Weredeselam Olango, MD, Bhrugav Raval, MD, David Marks, MD

From the Department of Neurology, Rutgers-New Jersey Medical School, Newark.

Author contributions: Dr. Sheikh conceptualized, designed, and drafted the manuscript, obtained the multimedia, and created the images and videos. Dr. Olango revised the manuscript. Dr. Raval edited the manuscript and contributed to the final video. Dr. Marks revised and edited the manuscript for intellectual content and approved all final changes.

Acknowledgment: The authors acknowledge the help of Ms. Sheila Jackson in obtaining the video and the EEG from the system. Study funding: No targeted funding reported. 
Disclosure: The authors report no disclosures relevant to the manuscript. Go to Neurology.org for full disclosures.

Correspondence to Dr. Sheikh: Zubeda.karim@gmail.com

1. Trinka E, Walser G, Unterberger I, et al. Peri-ictal water drinking lateralizes seizure onset to the nondominant temporal lobe. Neurology 2003;60:873-876.

2. Musilova K, Kuba R, Brazdil M, et al. Occurrence and lateralizing value of "rare" peri-ictal vegetative symptoms in temporal lobe epilepsy. Epilepsy Behav 2010;19:372-375.

\section{WriteClick ${ }^{\circledR}$ rapid online correspondence}

The editors encourage comments about recent articles through WriteClick:

Go to Neurology.org and click on the "WriteClick" tab at the top of the page. Responses will be posted within 72 hours of submission.

Before using WriteClick, remember the following:

- WriteClick is restricted to comments about studies published in Neurology within the last eight weeks

- Read previously posted comments; redundant comments will not be posted

- Your submission must be 200 words or less and have a maximum of five references; reference one must be the article on which you are commenting

- You can include a maximum of five authors (including yourself)

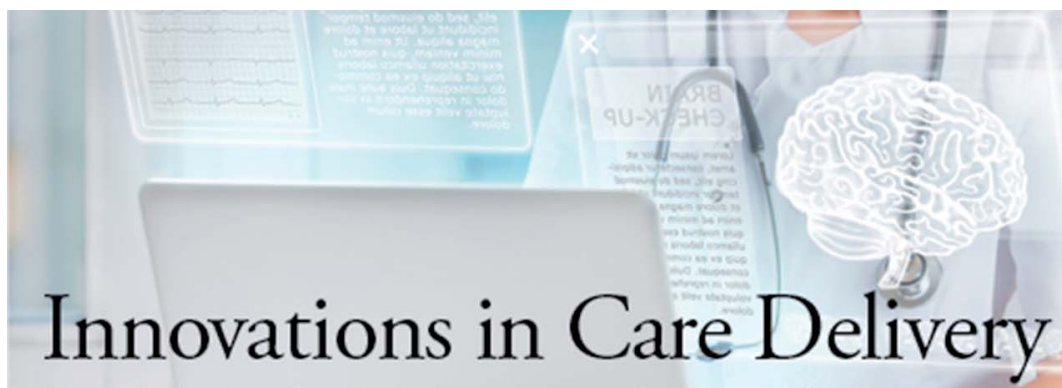

A curated collection featuring advances in neurologic care

\section{NEW!}

\section{Innovations in Care Delivery - A curated collection featuring advances in neurologic care}

This Neurology ${ }^{\circledR}$ special interest Web site provides a forum to explore new care models from multiple disciplines, access to sources on health care innovation, and expert opinions on current research from Neurology journals. Curated by E. Ray Dorsey, MD, MBA.

Stay ahead of the curve at Neurology.org/innovations. 


\title{
Neurology
}

\author{
Ictal water-seeking in nondominant temporal lobe seizures \\ Zubeda Sheikh, Weredeselam Olango, Bhrugav Raval, et al. \\ Neurology 2016;86;1847-1848 \\ DOI 10.1212/WNL.0000000000002662
}

\section{This information is current as of May 9, 2016}

\section{Updated Information \& Services}

\section{Supplementary Material}

\section{References}

Subspecialty Collections

Permissions \& Licensing

Reprints including high resolution figures, can be found at: http://n.neurology.org/content/86/19/1847.full

Supplementary material can be found at: http://n.neurology.org/content/suppl/2016/05/08/WNL.0000000000002 662.DC1

This article cites 2 articles, 0 of which you can access for free at: http://n.neurology.org/content/86/19/1847.full\#ref-list-1

This article, along with others on similar topics, appears in the following collection(s):

Complex partial seizures

http://n.neurology.org/cgi/collection/complex_partial_seizures EEG; see Epilepsy/Seizures

http://n.neurology.org/cgi/collection/eeg_see_epilepsy-seizures

Epilepsy monitoring

http://n.neurology.org/cgi/collection/epilepsy_monitoring_

Hippocampal sclerosis

http://n.neurology.org/cgi/collection/hippocampal_sclerosis

Video/ EEG use in epilepsy

http://n.neurology.org/cgi/collection/video_eeg_use_in_epilepsy

Information about reproducing this article in parts (figures,tables) or in its entirety can be found online at:

http://www.neurology.org/about/about_the_journal\#permissions

Information about ordering reprints can be found online:

http://n.neurology.org/subscribers/advertise

Neurology ${ }^{\circledR}$ is the official journal of the American Academy of Neurology. Published continuously since 1951, it is now a weekly with 48 issues per year. Copyright () 2016 American Academy of Neurology. All rights reserved. Print ISSN: 0028-3878. Online ISSN: 1526-632X.



